\title{
A talk with Albie Sachs
}

\author{
Albert Dzur*
}

Albert (Albie) Louis Sachs is one of the most important leaders in South Africa's struggles against apartheid and has made considerable contributions to the country's post-apartheid democratic reconstruction. At 20, in 1955, he participated in the Congress of the People, where the Freedom Charter was adopted. Following law school, he defended people charged under racial statutes and security laws. Jailed for this work, he eventually had to leave the country. In 1988, while in exile in Mozambique, Albie lost an arm and sight in one eye in a car bomb explosion planned by South African military operatives. Undaunted, he continued his activism, eventually taking part in drafting South Africa's democratic Constitution. In 1994, he was appointed to the Constitutional Court by Nelson Mandela and stayed as a justice on the court until 2009. An accomplished author, Albie is one of only two people to win the Alan Paton Award twice - in 1991 for his book The soft vengeance of a freedom fighter and in 2014 for The strange alchemy of life and law. A documentary about his life, Soft vengeance: Albie Sachs and the new South Africa, by filmmaker Abby Ginzberg, was released in 2013.

\section{An early commitment to social justice}

Dzur: Let's start back in time. Why do you think you've been driven by a commitment to social justice? You have written about your sense of privilege for having white skin, but lots of privileged people never question it. Why did you?

Sachs: I was born into questioning it. My dad Solly Sachs was the general secretary to the garment workers' union. He was fighting the bosses. He was fighting the state. He had a strong belief we were living in an unjust society. I discovered years later, going through old documents, that on my sixth birthday there were birthday greetings from him wishing me to grow up to be a soldier in the fight for liberation. This was during World War II. I didn't stand a chance.

My mother, Ray Sachs, was the typist for Moses Kotane. He was on the National Executive of the African National Congress in South Africa and General Secretary of the Communist Party of South Africa. She would say, 'Tidy up, tidy up, Uncle Moses is coming.' And it wasn't Moses Cohen or Moses Cantor, it was Moses Kotane, a black person for whom she had enormous respect and admiration. It just made it clear that racism was absurd, inhuman, unjust and plain wrong.

* $\quad$ Albert Dzur is Professor, Departments of Political Science and Philosophy, Bowling Green State University, USA. Contact author: awdzur@bgsu.edu. 
My white skin opened doors for me in education and even to imagining - if I wanted to be a scientist to discover a microbe smaller than Louis Pasteur did, or fly to the moon, or be a sailor to sail around the world or to write a great novel. Whatever it is, my imagination was wide open. I could just take having ambition for granted. Then, however, it became something else. I wouldn't say it was a curse. I am who I am, I happen to have a white skin. But the only way I could reconcile myself to the privilege that came with my pigmentation was to be involved in the struggle to overturn the system of white supremacy in South Africa.

Dzur: Why pursue social justice through the legal profession? I know this seems like an obvious question, but there are lots of ways you could have effected change. You could have been a poet, an educator or a journalist. Why use the tools of law?

Sachs: The law in South Africa was a major instrument of oppression. So, it also became a major instrument of resisting oppression: the more widespread the use of law, the more pervasive the resistance to the system through law. People asked you in your last year of schooling, 'Well, Albie, what are you going to do? What are you going to be?' I would say, 'I am going to be a doctor.' And suddenly it changed: 'I'm going to be a lawyer.' I don't know what made me change. But it was some vague and general sentiment that I could be useful, do something for fairness and justice and a better world through being a lawyer.

Dzur: Were there other lawyers you admired? I'm curious about what made you switch career paths.

Sachs: No. My dad, Solly, was a great litigator, but I didn't grow up in his home. My parents split when I was very young. So, I would read about him in the newspapers. He used the law as a trade union labour leader. He'd been involved in 23 different cases in his life. Quite a few of them made the law reports. He won most of his cases, but the two that are most cited are cases that he lost - his very first case and his very last one.

\section{Activism and the tensions between law and justice}

Dzur: Once you're on the bench of the Constitutional Court, I wonder if the activist standpoint ever clashed with the jurist standpoint in which you are confronted by the thought, "Albie the activist would say "yes" but Albie the Judge has to say "no"'.

Sachs: I was for much of my life in the resistance, in the underground. I would have called myself a revolutionary: for a number of years, a lawyer by day and an outlaw at night trying to overthrow the system in terms of which I was practising. The deepest tension I had was not between the manifest injustice of racist apartheid law and my convictions. That was obvious. It was a cruel, unjust and inhuman system denounced by the world. I had to fight against it. The split was a deeper one. It was between the claims of law to be universal, rational, fair, availa- 
ble for everybody and almost in itself introducing elements of non-arbitrariness and fairness in life and law, as experienced by the poor, overlaid with the fact that the poor were overwhelmingly black.

The professors who would be lecturing to me during the day would be inviting me into the world of fairness, justice, equity and rights - the beautiful phrases of the ages. They had a deep belief in a law as law. At night I would go down to the townships with people living in shacks and no electricity, just candlelight; you'd see the whites of the eyes, the whites of the mouths. The people hated the law. The law was the police van chasing them and throwing them into jail for not having their documents or not paying their debts. The law was the enemy, but they would give their lives for justice. The professors believed utterly in the law; the law wasn't the enemy. But they wouldn't give their lives for justice. That tension between law and justice for the great majority of South Africans was, in a sense, simplified by the manifest injustice of apartheid, which you could resist. That tore me in half.

It was only when we started writing the Constitution decades later that I realised that the great phrases of the ages would help the poor, could bring our nation together, could introduce notions of meaningful rights for everybody and could be empowering. And at the same time the passion, the commitment, the dedication of the poor could invest the legal document called the Constitution with the significance and the reverberation and vitality that it needed.

Helping to write the Constitution didn't just help to heal the nation, it helped to heal Albie - my own psyche. This was something I couldn't have achieved simply through rationality or belief. It was through the experience of getting together with people we called the enemy, who now became the other side, and hammering out basic foundational rules and principles for the nation and what it means to be a human being in our country in the world today, that I was able to fuse the great concepts and phrases of the ages - all themselves products of struggle, resistance to oppression in different countries in different ages - and connect them up with our struggle for justice and emancipation in South Africa.

In 1994, when we had our first democratic elections, I was able to step out of the political arena and to consider becoming a judge on the Constitutional Court because the Court was there to ensure that the basic normative system - set of values, institutions and procedures created by the Constitution - guided all exercise of public power. Our Constitution was such a transformative and progressive one that for me there is no rupture between being the political activist and becoming the judicial functionary. Basically, we were carrying forward the same principles and ideals into a different terrain.

The only time, though, that I actually experienced a short rupture was with the 2004 Port Elizabeth Municipality case where I was asked by the Chief Justice to write the lead judgement for the court to prepare in advance. This case involved about ten very poor black African families who had been evicted from their shacks in a particular area. They had found some vacant ground near a very upmarket, overwhelmingly white, suburb. They put up their shacks and had been there for a number of years. The white suburbanites eventually went to the local council, asked for these families to be evicted and the court ordered eviction. The matter 
was taken on appeal to our highest appellate court, below the Constitutional Court. They overturned the eviction, but on very flimsy technical grounds, and now there was an appeal by the state to the Constitutional Court.

I looked at the case and I thought, 'Well, I'm a judge. I've sworn to uphold the law and the Constitution without fear, favour or prejudice. You can't just come, in our society that has a property clause that says no one should be arbitrarily deprived of their property, to allow people to arbitrarily deprive the white landowners of their property by erecting shacks on their land. I've sworn to uphold the law and that's my duty as a judge.' But I thought, 'I as Albie, I can't do it because it's so unfair and so unjust. The whites have got their beautiful homes, and this is a piece of vacant land they are not using. We know why we have millions of black people dispossessed, landless and homeless. I can't as Albie. I've been fighting all my life against this kind of injustice and I can't order their eviction. And if I can't, then I've got to retire from the bench, which I didn't want to do. I love the work; it's fantastic work, fascinating and interesting.'

Fortunately for me, I was able to convert a private dilemma into a Constitutional tension. On the one hand, the Constitution protects owners of property from being arbitrarily deprived of the property, and on the other hand, our Constitution grants the right of everybody to have adequate housing. And that is subject to progressive realisation. It meant to find some kind of way forward. I remember saying in that case that in some cases there is no right answer. The legal philosopher Ronald Dworkin believed there is a right answer to every legal case, but my experience is different. I would never make that claim. All I could say is, as a judge, I would give it my best shot and all decisions are subject to change. They affect other decisions, they are overtaken, they develop a patina, they are undermined. There is an inherent mutability. It's the best you can do at that moment for that time, but it is always subject to mutation, to change; by its very nature it has to be. In any event, I decided that it wouldn't be just and equitable in those circumstances to order eviction until there had been meaningful engagement between all the interested parties with a view to finding a practical and fair solution, which could be, for example, finding alternative accommodation for the householders. That was that one moment of actual sharp clash between a judicial conscience and an activist conscience.

I published a book a year ago called, We the People: insights of an activist judge. In the thinking I did about it I came to the conclusion that in fact the most activist court in the world today is the US Supreme Court. It is the majority on the US Supreme Court who are striking down, in a very activist way, gun control decided by local people on the spot; who are striking down diversity promotion programmes in primary schools that the local people want; who are striking down campaign finance restrictions that have been agreed to on a cross-party basis in Congress with huge support; and striking down laws produced to improve access to voting. It's the most activist Court in the world. And the real question is, which side are you an activist on? Are you an activist on the side of power, of the privileged, of the most fortunate in society? Or, are you an activist as a judge on the side of those who mightn't be strongly represented in the organs of legislative 
and executive power but who have certain fundamental rights that ought to be respected?

\section{The court as a liberated zone}

Dzur: This gets to a related question. You have talked about feeling light and joyful when you came to work at the Constitutional Court. You've considered a number of possible reasons for this feeling, and say that the most important one is that the court 'is our little liberated zone, an exemplar of a non-racial, non-sexist society'. I want to ask you about this because light and joyful feelings are not commonly associated with courts. I wonder if that is because so many courts are not, in fact, liberated zones.

Sachs: This feeling has a very special South African significance. It was light and joy, a sense of elation that I couldn't quite understand. I'm a very secular person: when I die, I die. I don't believe there is a spirit that will depart from our body and inhabit some timeless and universal space. So, I'm not easily given to a notion of an inner essence that exists outside of or separate from the body. But this was a spiritual kind of experience. Simply driving to work and parking in the basement, which was very banal and dark and not joyous and not light at all, but I had that sense of uplift.

I wondered, is it because the court was built in the heart of a prison and represents transformation and change and human hope? Sure, that was part of it, but it wasn't just that.

Is it because our court happens to be not isolated from humanity and from society, but is physically located between a very densely crowded, very poor, very problematic part of Johannesburg connecting up with the wealthiest parts of Johannesburg and around the corner the most bureaucratic Johannesburg? Three towns that are normally separate from each other are united by the hill on which our court stands. I felt that was important, but that wasn't it. And it wasn't simply that we have a marvellous building that is very transparent, open, light, welcoming, warm, filled with art work and that is based on the notion of justice under a tree, which is the traditional African form of dispute settlement. That was there, but there was something more.

The something more was that South Africa still bears the imprint - in its physical structures, in its nomenclature, even in its arboreal growth - of colonialism and apartheid. If I go anywhere in the country, I feel that I'm a white person in a white space or in a black space, even though there's no legal differentiation anymore. I feel something pretty similar in most of the United States and in England, so it is not unique, but it is uniquely intense in South Africa. What we did with our court was not only choose a site in which black, white and brown had all been locked up - Mandela and Gandhi and Albert Luthuli and many others. It was a very momentous space in terms of everybody oppressing almost everybody there, very rich with layers of our history, a history of pain. Our court as a building was a building with a new architecture that drew on the best of all of our dif- 
ferent cultural infusions, a building that was light, friendly and warm, like justice under a tree. That was part of the feeling: a certain physicality, as opposed to the monumentality, the ornateness, the symbolism of state power. We had a court that symbolised restraints on state power, introducing elements of humanity into the functioning of government and state. That had quite a lot to do with the feeling. But it was even more than that; not just the building, it was our very institution, the range of the personnel. When we started off, because of the history of apartheid, out of the first eleven judges we had six white men, one white woman and the number of people of colour was reduced. By the time I left the elation I felt going in to our new court building was connected to the demographics of our court corresponding to quite a large extent to the demographics of the country.

It was because of the leadership and the diversity on the bench that I felt so comfortable in that place. During teatime I would hear different African languages being spoken by my colleagues. I didn't understand those languages because of my cultural backwardness, but I felt joy, I thought to myself, 'This is part of South Africa. You don't have to be English-speaking. We use English for our judgments, but you don't have to be English-speaking to be a judge and to do well on the court.' It went through to the secretaries, the administration staff. Somehow, we were a microcosm of what South Africa could become everywhere and in our thinking as well. It was the kind of thinking that transcended the categories of the past, that took account of race because race is still so overwhelmingly significant in our society, but took account of race to overcome race rather than pretending race is irrelevant - which allows those who are racially favoured to get along with their comfortable lives. It was a combination of these factors that made me feel this was a liberated zone in South Africa. We didn't use the word 'de-colonised' then, but it was as though at last I was inhabiting a truly decolonised space somewhere on this earth.

\section{Realism, idealism and 'soft vengeance'}

Dzur: Circling into this question about being a judge who is committed to ideals, you've noted that 'people have always said we should get real, but we never got real. And we never got over the idea that blacks and whites could live together under conditions of equality and dignity.' Judges are rule bearers; they are tinkerers with specific and concrete rules. Do you think it is important for judges to not get real?

Sachs: It depends. 'Get real' has a context. 'Get real' means, 'Climb down. Give up those grand ideals and compromise. Give in. Capitulate.' Sometimes it's even dirty: 'Get real, the world is a dirty place.' 'We never got real,' means the total rejection of that. It doesn't mean that, as idealists, we had to be unpragmatic. In fact, my experience has been the more intensely idealistic you are and the more committed and secure you are in your value system the easier it is to be pragmatic. Because you're not giving up on the principles; you're finding manageable, sustainable ways of achieving the ideal, working towards it. So, there isn't a ten- 
sion in that sense between idealism and pragmatism. The tension is between giving up on ideals, abandoning them, polluting them, on the one hand, and holding to them. Another way I have put it in previous writing, is to say, 'While we must always be sceptical about law's pretensions we should never be cynical about law's potentiality.' I think that scepticism actually aids idealism; it doesn't undermine idealism. Idealism permits and requires scepticism. They are in a certain kind of tension, but they're not contradictory.

Dzur: Soft vengeance is the title of a book of yours and also now a documentary about your life. I get the sense that you don't like the word 'vengeance' very much, but I wonder if you could say more about what the phrase means to you and, moving forward, what it suggests as an attitude towards people with whom you are in conflict.

Sachs: I didn't start with the phrase. I didn't find the phrase and say, 'What a great phrase.' It emerged in a very specific context. I'd been blown up by a bomb put in my car by a South African security agent. I lost my arm and sight in one eye. I am recovering in London in the hospital and I get a note from a friend of mine. It said, 'Don't worry comrade Albie, we will avenge you.' So, he introduces the notion 'avenge me'. I think, 'Avenge me? We are going to cut off the arm and blind in one eye? Is that the kind of country we are fighting for?' And I say to myself, 'If we get democracy, if we get freedom, that will be my soft vengeance. Roses and lilies will grow out of my arm.' Some weeks later I'm still in hospital and I hear that they caught one of the people responsible for placing the bomb. That was in Mozambique, where I was living in exile. If he is put on trial and the evidence is insufficient to prove beyond reasonable doubt that he's guilty and he is acquitted, that will be my soft vengeance, because then we are living under the rule of law.

That phrase, 'soft vengeance', popped into my head twice in rather acute emotional situations and it is a phrase that lifted me up. It was a very affirmative kind of a phrase and may be partly a psychological thing on my part. I remember being asked, in 1990, by Tony Lewis, who used to write op-ed pieces for The New York Times. He said, 'Albie, you're going back to South Africa now. Would you like Nuremberg Trials for the people who blew off your arm?' I said, 'Tony, I used to think during the struggle there was something wrong with me. I didn't hate the guards who were locking me up. I should have wanted to take a knife and plunge it into their backs, and I didn't.' And I felt this was a deficit: 'You call yourself a revolutionary and you don't hate the enemy! What's the matter with you?' He said, 'Albie, you can relax. I've spoken to Mandela and he said something similar. I've spoken to Kathrada and he said something similar. I've spoken to Sisulu and he said something similar.'

I realised it was part of our culture. It is a very affirmative and a very strong culture of belief in humanity, belief in your cause, belief in yourselves and your human solidarity. So, that phrase 'soft vengeance', in a way the very contradictory nature of that term, is transcendent. Sometimes people say, 'Albie knows how to forgive.' I've never used the word 'forgive'. I met the person who put the bomb in 
the car. He didn't say, 'Sorry I did it.' How can he say, 'Sorry I blew off your arm?' It is ludicrous. He was on that side and I was on this side. Now we are moving together into one country. And when he had gone to the truth commission and told them the truth I met him afterwards and I was actually able to shake his hand quite spontaneously. I almost fainted; it was a shock to me. He went away elated, but I heard afterwards he had gone home and cried for 2 weeks. For me, these emotions are worth much more for the humanising of people and their relationships and the destruction of the enmities that have been keeping us apart and the rage that has been consuming us - much more important than locking somebody up and sending them to jail - which would have done nothing for my arm.

Dzur: You are referring to Henri van der Westhuizen, a military intelligence officer who worked on planning the car bomb. You met him twice: once before the Truth and Reconciliation Commission (TRC) and once afterwards. Before, you have a good conversation, but you can't find yourself able to shake his hand. And then afterwards there is some change in him that you recognise and you are able to shake his hand. Here is a hypothetical: What if he had told you, 'Justice Sachs, I haven't gone to the TRC, but I have gone to my priest and I have made a confession and I feel much better about it.' How would you have responded? What difference did the public act of going to the TRC make to you that a more private, albeit religious, act would not have done?

Sachs: I can't even speculate on how I would have reacted. But I would have acknowledged the fact that he came to see me. That was important that he contacted me. He established a human connection with me. And it goes against my nature not to shake someone's hand when I say goodbye. I feel uncomfortable. I feel I'm disconnecting from another human being. But at that moment, quite intuitively, I felt what he had done - it was not personal, it wasn't because he had blown me up - but he'd been fighting on the side of an apartheid regime trying to destroy our advance to democracy. I can't just shake his hand as though nothing had happened. But I said, 'Go to the TRC, tell them what you know.' And that was important. This was the mechanism a democratically chosen Parliament had chosen for dealing with the atrocities of the past. And by his participating in that, he's accepting the new model of citizenship. Not just having the right to vote in a new South Africa. But he is making his contribution and his contribution now is truth - what really happened - not just in relation to me, but also in relation to others.

So, intuitively, I found myself responding to that. He was one of only two soldiers who went. Many police went to the TRC, but only two soldiers went and he was one of those two. It meant he was breaking ranks with his military comrades in order to go there, whatever his motive was. He could have just kept quiet, he could have hidden away, but he felt a need to go to acknowledge and he did that. 


\section{Lessons from the freedom movement and the TRC for restorative justice systems}

Dzur: The TRC was an extraordinary process. I'm wondering in what ways ordinary justice systems might incorporate some of the lessons from the TRC to help victims and offenders to humanise themselves, to attach themselves to the law in the way you are suggesting happened with you and Henri?

Sachs: I think there can be a huge recasting of the very nature of criminal justice drawing on the processes, the emotions and the imaginations involved in the TRC. It doesn't mean having a TRC will solve any given country's problems. It was a closely defined, fairly precise, very context-oriented response to immediate needs, with a very open-ended character. But the notion of restorative justice, which was really implicit in the TRC, meant: Don't simply think the only way you can get justice and accountability is through imprisonment, through death, through confiscation. There are other ways in which people could be held to account. Instead of holding them to account simply through state action against them for the violations, you hold them to account by getting the community to be involved in a manner which will not simply punish them for violating the norms of the community but encourage them to discover greater humanity inside themselves, help to resocialise themselves, rehumanise themselves by restoring connections with the society in terms of which they've committed their depredations.

It's fairly well known that juvenile justice using diversionary methods can be far more effective and achieve much greater results both short and long term through restorative justice techniques than punitive justice or accusatorial justice would normally do. I believe that can be extended well beyond simply dealing with juveniles on the basis that 'They're young, give them another chance, this is the time to do it.'

One reason for my confidence is that the notion is very strong in traditional African justice systems. In the case of murder, in traditional African society, this would be seen not simply as an individual who has violated the norms of the community and must be punished, but a problem involving two families. The family of the person responsible would feel they have failed because their member has done something that is damaging not just to an individual but to another family. The two families must get together, they must connect up and find ways and means of 'How did this come to happen, how can we compensate, what can be done to restore the equilibrium between us?' That was for the most serious crime in African society; it wasn't just for the most trivial crime or crime by the youngest.

A judicial colleague and I said this principle should also apply in cases of libel. Once you have established the defamation, instead of awarding punitive damages in money terms, the emphasis should be on getting an apology and a reconnection between the parties. Not just a forced apology, but a genuine acknowledgement of having traduced the litigant. That has now been by and large and accepted by the Constitutional Court, after we left the court, as the major approach. 
Dignity and reputation is not seen as something you can quote on the stock exchange as a security. It is validated not by saying you get a hundred thousand dollars or a million dollars for your reputation, but by the person responsible saying, 'I was wrong. Let's see how we can get it together and live together in one community again.' I see that approach having significance in the civil law, where it could be quite important in relation to certain kinds of injuries, and being relevant in criminal law quite generally.

Dzur: Your own experiences behind bars affected you enormously. I'm thinking especially about your solitary confinement. You had two stretches in prison and I wonder if that terrible personal experience has made you see punishment differently from other lawyers or judges who have never been behind bars.

Sachs: I certainly recommended that every judge should spend time locked up even knowing it's for only one night, say for 24 hours, even knowing you're going to come out again. Just to get a physical sense of being in a confined space and subject to the total dominion and control of somebody else. I certainly feel that; there is something experiential in it. You just feel from the beginning, 'There is something wrong with humanity if this is the only way we can do it.' I don't know better ways, but I do notice that in countries like Norway and Sweden and Denmark, 10 years jail is seen as a very long time, and very, very serious. And in the United States people get 65 years, 500 years - sentences like that. I don't think Americans can be all that different from Norwegians. I think your president would love immigrants from Norway, but maybe not if they came with those ideas.

Dzur: Do you ever feel resentment towards the judges who permitted your incarceration? Do you ever wonder, 'What on earth were you thinking, you bright men?'

Sachs: I had that rage when I was in my first spell of detention in solitary confinement.

\section{Dzur: Almost half a year!}

Sachs: As I was entering the office of my legal practice, I was whisked off to jail. I couldn't see lawyers, I couldn't see my family. There was no charge against me. There was no evidence against me. I felt a rage. Not only against my captors, but a greater rage against the legal system, against judges, against my colleagues. Then, after 27 days, the station commander comes in waving a piece of paper. I can't even read it properly. The only book I'd been allowed was the Bible and it had these thin pages with two columns. I was rationing myself to two-and-a-half columns a day so I wouldn't get through it too quickly. So, I can't read across the page; I'm reading and my eye goes down in the middle of the page. And I see the words go across the page and I realise it's a court order. The court order says I should be allowed reading and writing materials. So, now the judges and the legal system are the most magnificent human beings who ever existed in the whole of human history. Your emotions just get totally and utterly exaggerated. 
I did feel the two extremes of emotions in relation to the legal system then. I would often get very angry at the law's pretensions and maybe I have a special little bit of rancour directed towards judicial colleagues in other parts of the world who use the phrases of the law for the purposes of oppression, marginalisation and exclusion. I do feel a certain kind of anger, a sharp anger, maybe because we are so close that I feel it such an unfair utilisation of instruments and thoughts that could be so beneficial.

Dzur: Have judges from the old regime come to you and apologised?

Sachs: No. The nearest there has been, emerged from a very intense discussion by the Constitutional Court judges about whether the court and the judiciary as a whole should make submissions to the Truth Commission. The Truth Commission, in addition to hearing people who had stories about abuses and atrocities and also hearing people who came forward to acknowledge that they had violated the law and had done awful things, in addition asked the press, 'Where were you when all of these things were happening? Why did you carry all these stories full of disinformation?' In my particular case, one leading newspaper that would call itself 'liberal', had said, 'He who lives by the sword dies by the sword. Albie Sachs was more or less asking for the bomb; he shouldn't complain.' Why was the press doing that? I must say that particular editor very graciously himself apologised afterwards, by saying he had now heard me speak about fundamental rights and he realised he had been completely wrong.

Where was business? Where were the faith communities when all these things were happening? Where were the judges? And now we are considering what to do. We are divided more or less down the middle, and the judges who were the most keen to go to the Truth Commission were the progressive judges on our court who had done what they could under apartheid to soften the law to uphold decent principles. They said, 'We should have done more.' They wanted to go. But judges on other courts had blithely said, 'Oh that was just the law. It's not my job to criticize the law but to carry it out. I'm not responsible,' they felt they had nothing to apologise about. And the good judges wanted to apologise for not doing more.

In the end, there was a strong feeling that we didn't, now that we were building a new judiciary as an institution, want to split the judiciary into the 'goodies' and the 'baddies'. Also, the idea of the judiciary bending the knee to an executive organ displeased some. My feeling, however, was, 'This is a completely new dawn, it's a moment in history. We are apologising for the previous judiciary, in a way, we continue that judiciary but we start with an apology as we move forward. It is not an example of judges bending the knee to the executive.' So, the compromise was that four top judges from the two top courts sent a letter, a statement to the TRC saying that we failed in two major respects. One is the judiciary enforced overtly racist and oppressive laws. And secondly, that the judiciary failed to protect people from torture, to examine evidence of ill-treatment of witnesses of accused people, in a way it should have done that could have saved lives and provided appropriate judicial control. So, it is a very strong statement acknowledging 
serious failure, and as far as I know, it's the only judiciary in the world that's ever done that.

The statement was made, however, with a total lack of statecraft, if you like. Instead of telling the world about this, I don't think the press even carried the story and to this day, it is not publicly known. I think I am the only one who every 10 years or so answers a question like the one you just put to me. To indicate, in fact, that there was a strong mea culpa from our judiciary as an institution. But it was as an institution that we responded; it wasn't personal.

Dzur: I have one last question. Returning full circle to the theme of joy and lightness reflected in your life and work, I wonder what the source of your positive energy is. This is a time of significant scepticism in many countries about public institutions and the viability of meaningful social change. I wonder if you have suggestions for where to root or anchor a sense of possibility, positive collective action and social optimism?

Sachs: I think it's partly that we didn't 'get real', and we got a fantastic country with a great Constitution. We've got a country - we didn't even have a country. So, that solidifies in me optimism, the possibilities of achieving things, not just something better than what it was, but something wholly different. And right now as I give this interview it is reinforced because we have a great new president who was very active in negotiating our Constitution and who is taking very decisive steps in dealing with corruption, and abuse of powers and state capture. It mightn't last. Who knows what might happen? But it has been a great vindication in South Africa of constitutionalism, of values, the role of institutions, the role of civil society and possibilities inside political parties. The major battle was inside the African National Congress. He emerged on top because he represented precisely the forces of optimism, of belief in humanity, belief in honesty and integrity, a belief in constitutionalism. It is a good time to be asking me the question right now.

Even in the dark days a few years back people would ask me, 'Albie, if you look at South Africa today the inequality is enormous, racism is still everywhere, there's massive unemployment, intolerable levels of crime, and there's corruption in very high places and in low places. Is this is the country you were fighting for?' I would say, 'Yes! It is the country we were fighting for, but no it is not the society we were fighting for. We have got to use the country to get the society.' We glory in the country being our people, being our Constitution, being our institutions and being in the consciences of our people. We want to use that and use the rights that we have won to now deal with all the other problems that I've mentioned.

Our institutions have been working well. The judiciary in particular in South Africa has played a brilliant role and I'm speaking after I left the bench - it is not self-congratulation - where a completely new generation of judges has really been upholding the Constitution and calling the president to account, calling Parliament to account. And instead of a strong affirmation of judicial insistence on upholding the Constitution creating a kind of overreach that would stifle Parliament, it has revitalised Parliament, it has reinvigorated the press, it has given 
strength to the honest public servants to do their work properly and not to feel that they are going to be crushed if they don't go along with intrigue and corruption.

So, that's a level of optimism that hasn't left me. There was a large group of people, called 'the 102 veterans and stalwarts', who were all veterans of our struggle for freedom in South Africa. They were extremely indignant about the corruption and about the abuse of office. They spoke out against their own comrades from their own organisation. I didn't join them because I felt as a former judge this was so political it would be inappropriate for me to be involved. But I noticed what they were doing, and I noticed how responsive society was, how pleased to see that people who were in the struggle at the time of Mandela were speaking out. There's a certain continuity of the tradition of honesty and integrity. It's not to say that we didn't go wrong, or make mistakes or fall - many of us did. But there is that current of integrity that held us together in the dark days, and that gave us a country. And it is restoring that current of integrity that is so valuable.

I was recently in the United States and many of my friends are so disheartened and so downhearted. I would say I've been to the United States when a certain president was waging war in another part of the world - in fact I've been there twice when presidents have been waging war in another part of the world and Americans have been extremely indignant. And they ended those wars. It's that stubbornness, if you like, in favour of the values of freedom, justice and human emancipation that I feel keeps individuals going and enables countries to emerge from what appear to be awful forms of leadership and domination. 